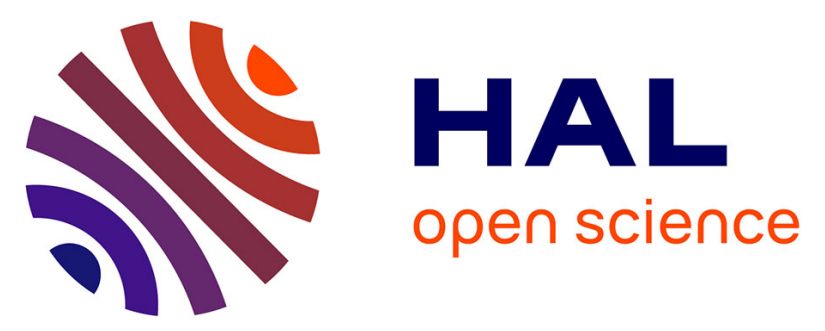

\title{
A stegosaur tooth (Dinosauria, Ornithischia) from the Early Cretaceous of southwestern France
}

\author{
Jean-Paul Billon-Bruyat, Jean-Michel Mazin, Joane Pouech
}

\section{To cite this version:}

Jean-Paul Billon-Bruyat, Jean-Michel Mazin, Joane Pouech. A stegosaur tooth (Dinosauria, Ornithischia) from the Early Cretaceous of southwestern France. Swiss Journal of Geosciences, 2010, 103 (2), pp.143-153. 10.1007/s00015-010-0028-y . hal-00670066

\section{HAL Id: hal-00670066 https://hal.science/hal-00670066}

Submitted on 27 Nov 2021

HAL is a multi-disciplinary open access archive for the deposit and dissemination of scientific research documents, whether they are published or not. The documents may come from teaching and research institutions in France or abroad, or from public or private research centers.
L'archive ouverte pluridisciplinaire HAL, est destinée au dépôt et à la diffusion de documents scientifiques de niveau recherche, publiés ou non, émanant des établissements d'enseignement et de recherche français ou étrangers, des laboratoires publics ou privés.

\section{(c)(1)}

Distributed under a Creative Commons Attribution| 4.0 International License 


\title{
A stegosaur tooth (Dinosauria, Ornithischia) from the Early Cretaceous of southwestern France
}

\author{
Jean-Paul Billon-Bruyat • Jean-Michel Mazin • \\ Joane Pouech
}

Received: 12 February 2010/Accepted: 22 July 2010/Published online: 2 September 2010

(C) Swiss Geological Society 2010

\begin{abstract}
The spotty nature of the terrestrial fossil record for the Mesozoic hinders a more complete understanding of dinosaur diversity. For stegosaurs (Ornithischia), the plated dinosaurs, only a few and fragmentary remains are reported from the Early Cretaceous of Europe. A recent revision concluded that only a partial vertebra of the nomen dubium Craterosaurus (?Aptian, England) could be considered as stegosaurian. Here we report on a stegosaur tooth from the Early Cretaceous (Berriasian) Purbeckian deposits of Cherves-de-Cognac (Charente), southwestern France. This tiny tooth was examined in detail using microtomography. Comparisons being limited by the rarity of stegosaur tooth rows material (e.g., from the skull of the holotype of Stegosaurus stenops) and dental material, notably from Europe, we observed new material of cf. Stegosaurus armatus and Hesperosaurus mjosi from the Upper Jurassic Morrison Formation of Wyoming (USA). The tooth shows
\end{abstract}

Editorial handling: Daniel Marty.

J.-P. Billon-Bruyat $(\square)$

Section d'archéologie et paléontologie, Office de la culture,

République et Canton du Jura, Hôtel des Halles,

2900 Porrentruy, Switzerland

e-mail: jean-paul.billon@palaeojura.ch

J.-M. Mazin

UMR 5125 PEPS, CNRS, Université Lyon 1,

Campus de la Doua, Bt. Géode,

69622 Villeurbanne Cedex, France

J. Pouech

European Synchrotron Radiation Facility, 6 rue Horowitz,

BP 220, 38046 Grenoble Cedex, France the most similarities to the Late Jurassic genera Stegosaurus and Hesperosaurus, but differs in having a distinctive downwardly arched (V-shaped) cingulum on the ?lingual face (maxillary tooth hypothesis). It is referred to as Stegosauria indeterminate, a medium-sized quadrupedal herbivore that inhabited an emerged land between the Armorican Massif and the Massif Central. This finding is the first evidence of a stegosaur from the Early Cretaceous of France and a welcome addition to the meagre European record of that time. In addition, it is the second stegosaurian tooth crown reported from Europe. The assemblage of ornithischians of Cherves-de-Cognac shares some similarities with that of the Early Cretaceous (Berriasian) of the Purbeck Limestone Group, southern England. The relative rarity of ornithischian osteological remains in both Purbeckian environments suggests that most of these dinosaurs were mainly inhabitants of inland terrestrial palaeoenvironments.

Keywords Stegosauria - Tooth · Berriasian · France · Fossil record $\cdot$ Microtomography

\section{Institutional abbreviations}

CHE Cherves-de-Cognac collection, Musée d'Angoulême, France

HMNH Hayashibara Museum of Natural History, Okayama, Japan

LHNB Laboratório des História Natural de Batalha, Portugal

SMA Sauriermuseum Aathal, Switzerland

USNM National Museum of Natural History (formerly United States National Museum), Washington, DC, USA

YPM Peabody Museum of Natural History, Yale University, New Haven, Connecticut, USA 


\section{Introduction}

The Stegosauria, the plated dinosaurs, are medium to largesized quadrupedal herbivorous ornithischians, with proportionally small heads and tiny teeth, and known with confidence from the Middle Jurassic to the Early Cretaceous (Galton and Upchurch 2004; Maidment et al. 2008). The European stegosaurs are well represented in the Middle-Late Jurassic but their fossil record is poor in the Early Cretaceous (see Maidment et al. 2008 for a recent review; Mateus et al. 2009 for Miragaia from Late Jurassic of Portugal). Such an apparent huge fall in biodiversity at the Jurassic/Cretaceous boundary (ca. 145.5 Myr ago) is known in non-marine tetrapods (amphibians, reptiles, birds, mammals) and has been mainly interpreted as a failure in rock deposition during the Early Cretaceous (Haubold 1990; Benton 1995), although it has been shown that new collecting is improving the completeness of the fossil record at this time (Fara and Benton 2000). In the same way, French stegosaurs have been recovered in the Middle-Late Jurassic (Buffetaut et al. 1991; Allain and Pereda Suberbiola 2003; Buffetaut and Morel 2009), but no stegosaurs are known in the Early Cretaceous. Here, we report the discovery of a stegosaur tooth from the Early Cretaceous (Berriasian) of Cherves-de-Cognac (Charente), southwestern France.

Vertebrate remains from this locality were reported as early as the middle of the nineteenth century (Coquand 1860). They belong to rich and diverse continental assemblages including chondrichthyans, osteichthyans, lissamphibians, turtles, lepidosaurs, crocodylians, dinosaurs, pterosaurs, birds and mammals (Buffetaut et al. 1989; Hervat and Hervat 1993; Vignaud et al. 1994; Le Loeuff et al. 1996; Billon-Bruyat 2003; Mazin et al. 2006; Pouech et al. 2006; Pouech 2008). Our team has excavated more than 1,800 macro-remains and 45,000 micro-remains of vertebrates, but only a single isolated stegosaur tooth was recovered. This find of a stegosaur is a welcome addition to the scanty European record of this dinosaur group during the Early Cretaceous.

\section{Geographical and geological setting}

The tooth was unearthed in 2002 by our crew during excavations in the gypsum Champblanc Quarry, near the village of Cherves-de-Cognac (administratively named Cherves-Richemont), at about $7 \mathrm{~km}$ north of the town of Cognac (département Charente), southwestern France. The outcrop (ca. $40 \mathrm{~m}$ thick) corresponds to a Purbeckian facies, overlying the Late Jurassic (Tithonian) marine limestones of the region (Bourgeuil et al. 1986). Using three independent biomarkers (ostracods, charophytes and dinoflagellates), this Purbeckian facies has been dated to the Early Cretaceous, precisely to the Berriasian, and correlated with the lower part of the Middle Purbeck of southern England (Colin et al. 2004; El Albani et al. 2004).

The series consists of gypsum, clays, marls and limestones, deposited in a succession of shallow hypersaline, brackish and freshwater conditions; see El Albani et al. (2004, 2005), Mazin et al. (2006) and Pouech (2008) for a detailed description and interpretation of the section. The tooth was recovered in the "Highly Fossiliferous Zone", a complex of glauconitic marls and limestones (ca. $1.3 \mathrm{~m}$ thick) in the middle part of the section. This zone contains accumulations of reworked assemblages of non-marine vertebrates, deposited in brackish waters of a deltaic environment; the rarity of marine vertebrates indicates that the communication with the open sea was limited. The vertebrate fossils are generally isolated, randomly oriented and sorted, without abrasion but with clean breaks, suggesting a short but high-energy transport by rivers and periodic flooding from the adjacent emerged land. This is consistent with the preservation of the reported tooth (Fig. 1), which shows a well-preserved crown and a broken root extremity covered by matrix (i.e. it was broken before fossilization).

The reported tooth was discovered in the marls of the richest level (C36) of this fossiliferous complex, along with aquatic (chondrichthyans, osteichthyans), amphibious (lissamphibians, turtles, crocodylians), terrestrial (lepidosaurs, crocodylians, dinosaurs, mammals) and aerial (pterosaurs, birds) forms (for lists see Billon-Bruyat 2003; Mazin et al. 2006; Pouech et al. 2006; Pouech 2008).

In terms of palaeogeography, the studied area corresponds to the northern margin of the Aquitaine Basin, between the Armorican Massif and the Massif Central (Ziegler 1988; Thierry et al. 2000). During the Tithonian, the Aquitaine Basin was likely occupied by a gulf (the "golfe charentais") connected/opening westwards to the opening North Atlantic Ocean (Delfaud and Gottis 1966; Hantzpergue and Lafaurie 1994). The Late Jurassic marine regression in Western Europe (Hallam 2001) led to the development of confined environments in this gulf, as evaporitic facies from the region of Cognac (Delfaud and Gottis 1966; Hantzpergue and Lafaurie 1994), until the Berriasian in the Champblanc Quarry. In all likelihood, this stegosaur inhabited an emerged land adjacent to such evaporitic environments. This was followed by a failure in rock deposition and/or subsequent erosion until the Cenomanian transgression (Bourgeuil et al. 1986). 


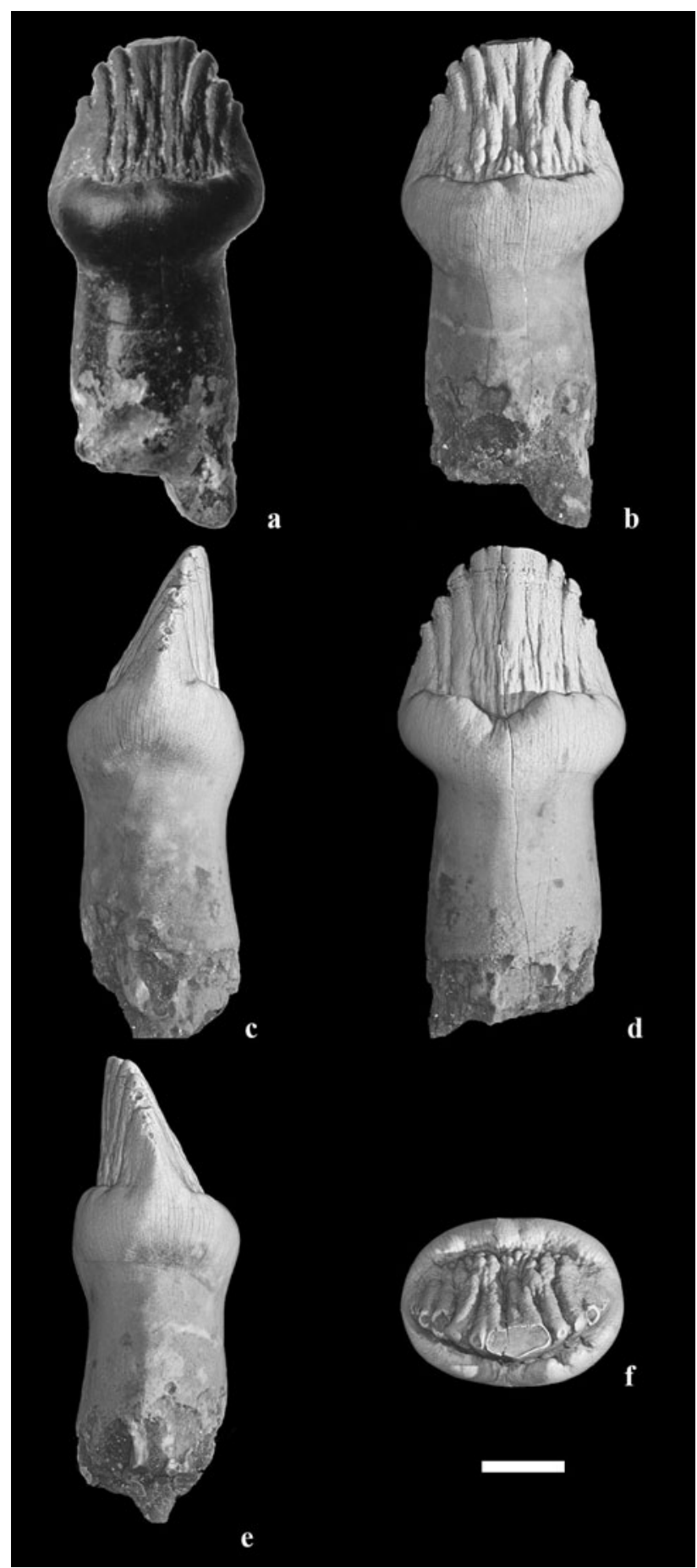

Fig. 1 Cheek tooth of Stegosauria indet. (CHE02.084), from the Berriasian (Lower Cretaceous) of Cherves-de-Cognac, near Cognac (Charente, France). a Photograph in ?labial view. b-f 3D reconstruction (X-ray Synchrotron microtomography ESRF, pixel size $5.6 \mu \mathrm{m}$, propagation distance $50 \mathrm{~mm}$, energy, $20 \mathrm{keV}$ ), in ?labial (b), ?mesial (c), ?lingual (d), ?distal (e) and apical (f) views. The different views are interpreted according to the hypothesis that CHE02.084 is a left maxillary tooth. Scale bar $2 \mathrm{~mm}$

\section{Systematic palaeontology}

\section{Ornithischia SEELEY 1887}

Thyreophora NopCSA 1915 (sensu Norman 1984)

Stegosauria MARSH 1877

Stegosauria indet. (Fig. 1)

Material

An isolated tooth, $\mathrm{n}^{\mathrm{O}}$ CHE02.084, stored in the palaeontological collection of the Musée d'Angoulême, Charente, France.

Methods

To examine this tiny tooth in detail, J. Pouech, J.-M. Mazin and P. Tafforeau performed a three-dimensional reconstruction based on microtomographies (Fig. 1b-f) at the European Synchrotron Radiation Facility (Grenoble, France), ID 19 beamline (pixel size $5.6 \mu \mathrm{m}$, propagation distance $50 \mathrm{~mm}$, energy $20 \mathrm{keV}$ ). The three dimensional processing and rendering were made with the software VGStudiomax (under ESRF Licence).

\section{Description}

The specimen is a well-preserved isolated tooth lacking the distal part of the root (Fig. 1). The crown is complete and thinly enamelled on both sides. This simple spatulate tooth consists of an expanded, transversely compressed, vertically striated crown having denticulate margins, a small wear facet situated on the apical tip, a prominent ring-like cingulum (swelling, shelf of enamel fully encircling the base of the crown), and a subcylindrical root. Above the cingulum, the crown is mesiodistally rounded and quite symmetrical (Fig. 1b, d), while it is labiolingually compressed and asymmetrical, and triangular in shape: one face is oblique and slightly concave, while the other is vertical and somewhat convex (Fig. 1c, e). Subvertical coarse ridges, semicircular in cross section, divide the lingual and labial surfaces of the crown and tend to merge with the cingulum; these ridges are divided by narrow grooves and become smaller toward the cingulum (Fig. 1b, d). The ridges and grooves are more pronounced on the concave crown face (Fig. 1b). The ridges terminate in large, upright marginal denticles where they intersect the cutting edges. Seven denticles are obvious on this crown, two of which show complete, slightly rounded tips (Fig. 1f; other tips are broken) somewhat hooked towards the crown apex (Fig. 1b, d, f); in addition, according to the number and 
size of ridges, two to three central denticles were strongly abraded at their tip by the wear facet, borne by the concave crown face and slightly obliquely inclined (Fig. 1b, f). Consequently, there was a total series of nine to ten denticles along the edge of the crown, with an equal number of four or five denticles, on each side of a main apical denticle or of the mesiodistal vertical axis of the crown, respectively. There are some/a few short and small secondary ridges visible at the base, mainly on the oblique crown face, just above the cingulum. The cingulum is smooth, perpendicular to the tooth axis (Fig. 1b, d), and well developed both lingually and labially at about the same level. It is slightly more pronounced on the oblique face and slightly higher on the vertical face (Fig. 1c, e, f). Its shape is, however, different on the two crown faces: almost straight on the oblique face (Fig. 1b), while it is downwardly arched, V-shaped, and vertically constricted on the vertical face (Fig. 1d). Mesiodistally, one side of the cingulum forms a more acute angle with the root at the neck (Fig. 1b, d). The distal part of the root is missing. The preserved part is straight, subcylindrical in cross section but slightly compressed labiolingually. Relative to the axis of the root, the crown is vertically aligned in mesiodistal views (Fig. 1b, d), whereas it is angled in labiolingual views (Fig. 1c, e).

Tooth measurements The tooth has a maximum height of $10 \mathrm{~mm}$ (crown and root, as preserved), a maximum width of $4.4 \mathrm{~mm}$ (mesiodistally, at the cingulum), and the crown has a maximum preserved height of ca. $4.8 \mathrm{~mm}$ (at the base of the cingulum). The root has a maximum diameter of $3.3 \mathrm{~mm}$ mesiodistally and $3.0 \mathrm{~mm}$ labiolingually (at the preserved distal end).

\section{Comparisons}

The morphology and ornamentation of this tooth indicate that it can be assigned to an ornithischian dinosaur of the thyreophoran group, more precisely to a stegosaur.

\section{A stegosaur tooth}

Among thyreophorans, an autapomorphy of the eurypods (Stegosaurus, Ankylosaurus, and their most recent common ancestor and all of their descendants; Sereno 1998) is the presence of a prominent, ring-like cingulum on maxillary teeth (reversed in Gastonia and Huayangosaurus), similar in development to that in Stegosaurus (Galton and Upchurch 2004; Maidment et al. 2008). This is also observed on the reported tooth. Among eurypods, teeth of stegosaurs can be distinguished from those of ankylosaurs by several criteria:

1. Among ankylosaurs, the Ankylosauridae have a swollen base but without a distinct cingulum while the Nodosauridae commonly have a conspicuous cingulum, which is typically higher on one crown surface than the other, giving a more asymmetrical section to the nodosaurid teeth (Coombs and Maryańska 1990) than in stegosaurs (Galton 1990; Galton and Upchurch 2004); on CHE02.084, the presence of a prominent cingulum, which is at about the same level on each crown surface, indicates that this tooth is more consistent with the stegosaurian condition.

2. The shape of the tips of the denticles is different in stegosaurs and ankylosaurs: the denticles tend to end in a sharp point in ankylosaurs (Coombs and Maryańska 1990; Barrett 2001; Vickaryous et al. 2004) whereas they are more rounded in stegosaurs (Gilmore 1914; Galton 1990, 2007; Barrett 2001; Galton and Upchurch 2004). On CHE02.084, the tips of denticles are slightly rounded and blunt, not pointed as in ankylosaurs.

3. In stegosaurs, the denticles generally continue onto the adjacent surface (to a varying extent) of the crown as well-marked ridges-semicircular in cross section(Galton 1990, 2007; Sander 1997; Galton and Upchurch 2004), as on CHE02.084, while vertical ridges in ankylosaur crowns-when present - have a more crested aspect (e.g., Vickaryous et al. 2004: fig. 17.13.A, F).

4. The apical denticle of stegosaurs-when present-is generally on the median vertical line of the crown, not posterior to it as in the teeth of ankylosaurs (Gilmore 1914; Coombs 1990). On CHE02.084, even though no apical denticle is preserved, the mesiodistal symmetry is not consistent with the ankylosaurian condition.

Based on the above differences, the reported specimen is identified as a stegosaurian tooth.

\section{Affinities amongst Stegosauria}

Complete stegosaurian tooth rows are extremely rare for comparison and usually preserved in such a way that, as underlined by Barrett (2001), it is hard to examine the teeth in detail. Consequently, the comparison of teeth in terms of form, ornamentation, orientation or size is difficult, notably for isolated and single teeth. CHE02.084 displays the characteristic features of stegosaurian cheek teeth (Gilmore 1914; Galton 1990, 2007; Sander 1997; Galton and Upchurch 2004), quite similar to those of other primitive ornithischians (Barrett 2001). The premaxilla of stegosaurs is edentulous, except in the basal form Huayangosaurus (BathonianCallovian, Lower Shaximiao Formation, China), in which the premaxillary teeth have a weakly developed cingulum (Galton 1990; Galton and Upchurch 2004), so CHE02.084 is a maxillary or a dentary tooth. The selection of stegosaur teeth figured by Galton (1990: fig. 21.4) or Galton and Upchurch 
(2004: fig. 16.5) - the same figure-shows various patterns of ornamentation of cheek tooth crowns. Among the figured teeth, CHE02.084 resembles those of Stegosaurus more closely (Galton and Upchurch 2004: fig. 16.5.A-D) than those of other genera (Kentrosaurus, Paranthodon, Huayangosaurus, Tuojiangosaurus; Galton and Upchurch 2004: figs.16.5.E-L). As in Stegosaurus, the crown outline is rounded, quite symmetrical mesiodistally, without an important primary ridge, and the cingulum is prominent and limited to the base of the crown. Based on comparisons with the skull of the holotype of Stegosaurus stenops USNM 4934 (Kimmeridgian-Tithonian, Morrison Formation, Wyoming, USA), with mostly maxillary teeth exposed, the teeth of which were described by Gilmore (1914) and recently by Galton (2007), we can attempt to identify whether CHE02.084 is a maxillary or a dentary tooth. The maxillary teeth of USNM 4934 show that: the labial face is slightly concave vertically (as Fig. 1b in CHE02.084) and the lingual face is slightly convex (as Fig. 1d in CHE02.084); the crown shows a slight degree of asymmetry when viewed in mesial or distal views (as Fig. 1c, e in CHE02.084), curving slightly lingually (as against slightly labially for dentary teeth); and the cingulum is slightly more pronounced labially (as Fig. 1b in CHE02.084). The mesiodistal asymmetry of the crown mentioned by Galton (1990) or Galton and Upchurch (2004), with a convex mesial outline bearing fewer and/or larger marginal denticles (contrary to what is observed in ankylosaurs by Coombs 1990), and a slightly concave distal outline with smaller denticles, is unclear here. Even though some denticles are broken or worn, the mesial and distal outlines seem quite symmetrical, convex, with similar marginal denticles in terms of number and size. Another character could be used to identify the mesial and distal sides: the cingulum forms a more acute angle with the root on the mesial side (Fig. 1b, c), as seen in different teeth of stegosaurs (e.g., Galton and Coombs 1981: figs. 1K-N; Galton and Upchurch 2004: fig. 16.5A, G, H, K; Galton 2007: figs. 2.5F, G). If these observations

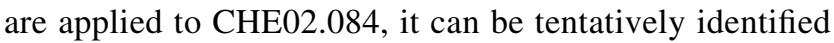
as a left maxillary tooth, keeping in mind that it is difficult to demonstrate as the teeth of USNM 4934 show little variation in form (Galton 2007).

As in other stegosaurs, the denticles of the reported tooth CHE02.084 continue onto the adjacent surface of the crown to a varying extent, but only in Stegosaurus is there a complex network of secondary, faint vertical ridges (Galton and Upchurch 2004: fig. 16.5.A). Even though some short and small ridges are visible at the base of the labial crown face of CHE02.084, there is no complex of secondary ridges as occurs in Stegosaurus. CHE02.084 has nine to ten denticles, that is less than generally observed in Stegosaurus and other stegosaurs, except in Kentrosaurus (Kimmeridgian, Tendaguru Formation, Tanzania), where there are only seven denticles (Galton and Upchurch 2004), but the simple crown of this genus, notably with a weak ring-shaped cingulum (Galton and Upchurch 2004: figs.16.5.E, F), is clearly different. Gilmore (1914) observed that the number of denticles is a variable character in USNM 4934, with as few as four to as many as seven denticles on each side of the apical one, which is consistent with the reported specimen. As explained by Galton (2007, p. 26), the tooth YPM 1938 used (as Stegosaurus ungulatus) by Marsh (1896) and Gilmore (1914: fig. 11) to characterize the teeth of Stegosaurus, is from a juvenile individual (a Stegosauridae incertae sedis), as shown by: size, but also by having less marginal denticles, each of which has a supporting vertical ridge (contrary to the crowns of the adult skull of S. stenops USNM 4934; Galton 2007: figs. 2.5D-F, 2.6A-D), and possibly by having no surface texture. These elements are consistent with CHE02.084. Another small tooth (USNM 7474) figured by Galton (2007: fig. 2.4D-F, Stegosauridae incertae sedis), shows the same ornamentation. In the same way, the cheek teeth of the holotype (HMNH 001) of the stegosaurid Hesperosaurus mjosi were described by Carpenter et al. (2001) as similar to those of Stegosaurus (except proportionally larger relative to skull size than S. stenops). However, Galton (2007, p. 25) noted that the figured tooth (Carpenter et al. 2001: fig. 3.5B) differs from those of S. stenops (USNM 4934) "in having coarse rounded subvertical ridges covering the apical half of the crown, one per marginal denticle, and the fine striations are only weakly developed"; this is consistent with CHE02.084. Consequently, the striation of the reported crown resembles those of Stegosaurus (notably juveniles) and Hesperosaurus more closely than those of other genera.

In the framework of the Symposium on Stegosauria (Sauriermuseum Aathal, June 2009), we had the opportunity to examine new dental material referred to cf. Stegosaurus and Hesperosaurus, from the Upper Jurassic Morrison Formation of Wyoming (USA), found by the crew of H.J. Kirby Siber (Siber and Möckli 2009; Carpenter 2010).

Firstly, we did a comparison with an important set of 46 teeth (more or less complete and prepared; 4 still in alveoli and 42 isolated and found in the surrounding matrix of a skeleton) of cf. Stegosaurus armatus (specimen "Sarah", SMA 0173-DS-RCR2003-02). This comparison shows that:

1. The presence of a main apical denticle is not evident, on the contrary there is rather a mesiodistal vertical axis separating two central ridges terminating in two denticles (e.g., Fig. 2a), as suggested for CHE02.084 (Fig. 1b).

2. A similar or more developed (up to mid-crown height) apical wear surface is sometimes present (Fig. 2b, c, f). 
Fig. 2 Isolated cheek teeth of cf. Stegosaurus armatus (SMA 0173-DS-RCR2003-02, specimen "Sarah"), from the Kimmeridgian-Tithonian (Late Jurassic) Morrison Formation of Red Canyon Ranch, near Shell (Big Horn County, Wyoming, USA). a Tooth $\mathrm{n}^{\circ} 235$ in lingual or labial view. b Tooth $\mathrm{n}^{\mathrm{o}} 269$ in lingual or labial view. $\mathbf{c}-\mathbf{e}$ Tooth $\mathrm{n}^{\mathrm{o}} 249$ in lingual or labial (c,

e) and mesial or distal

(d) views. f Tooth $\mathrm{n}^{\mathrm{o}} 231$ in

?lingual view. $g$ Tooth $\mathrm{n}^{\circ} 140$ in lingual or labial view. The teeth except $\mathrm{n}^{\circ} 269$ (b) are still partly embedded in matrix. Scale bar $2 \mathrm{~mm}$
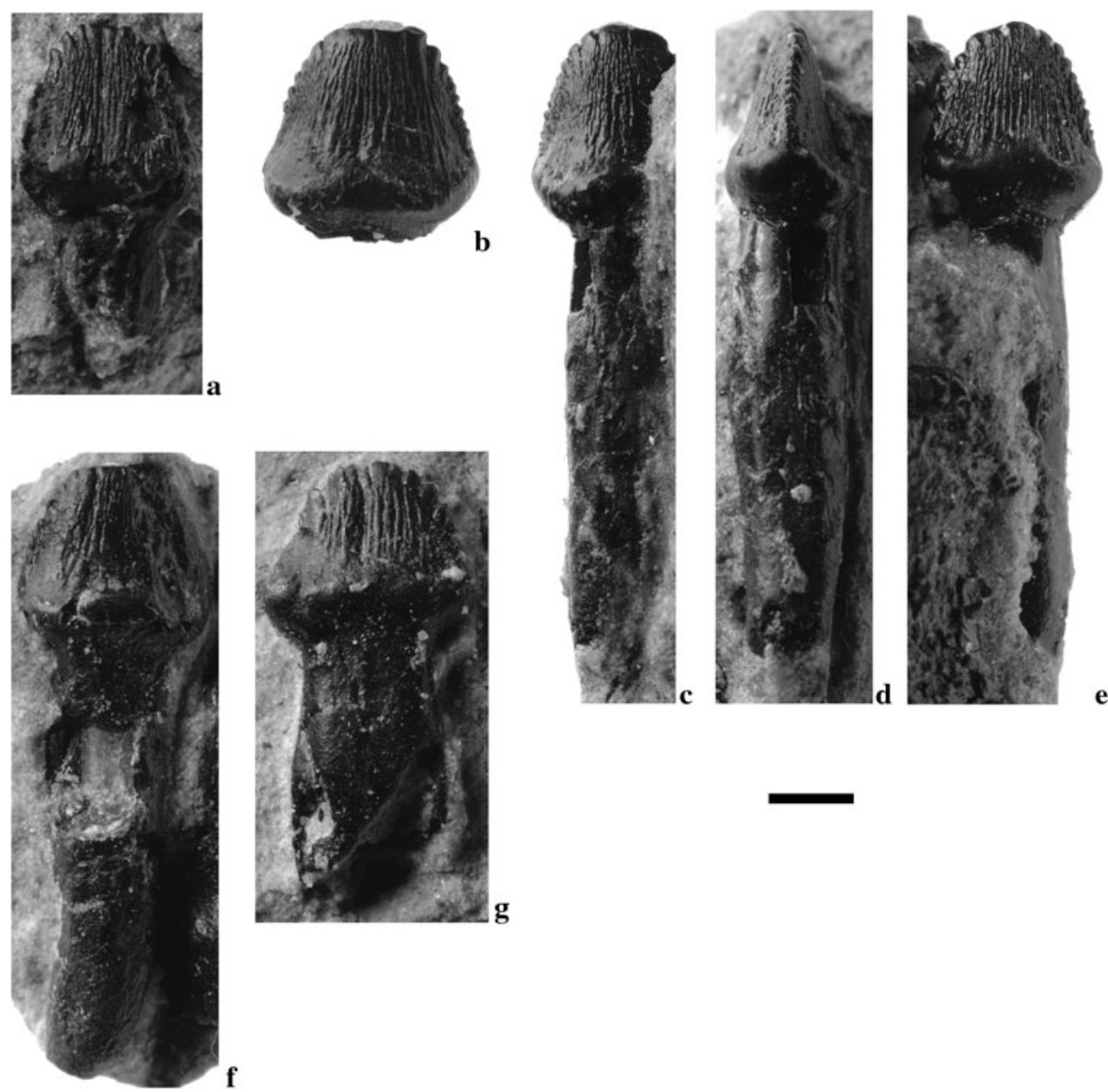

3. The cingulum is less prominent than in CHE02.084 and slightly upwardly arched on one face (Fig. 2e), as in S. stenops USNM 4934 (Galton 2007: fig. 2.6B, lingual face of the maxillary tooth 20), while it is downwardly arched in CHE02.084 (Fig. 1d, on the ?lingual face).

4. The root is also straight, subcylindrical, slightly compressed labiolingually (Fig. 2d), complete roots show a pointed end that is curved, most likely distally (Fig. 2f); some root extremities are broken as in CHE02.084, giving a stocky aspect to the tooth (Fig. $2 \mathrm{~g}$ ). The presence of the root in CHE02.084 indicates that it was a functional rather than a spent tooth, the root being resorbed in tooth loss as the incoming replacement tooth pressures the old crown (Sander 1997). In addition, the observation of similar broken roots found close to a cf. Stegosaurus skeleton confirms that it does not imply a long transport for CHE02.084.

Secondly, we did a comparison with teeth of skeletons referred to Hesperosaurus mjosi by Carpenter (2010): a single isolated tooth (specimen "Moritz", SMA 3074-FV01, Fig. 3) and a left maxillary dentition (specimen "Lilly",
SMA 0092, Fig. 4). As the mandibles of SMA 0092 are preserved in tight articulation with the skull, the teeth are only visible from one side and we cannot see if the opposing maxillary and dentary teeth interlock. Nonetheless, the following characteristics can be added for teeth of $H$. mjosi:

1. Well-developed fine striations (Fig. 4), as in cf. S. armatus (Fig. 2) or S. stenops USNM 4934, but contrary to the tooth of the holotype of $\mathrm{H}$. mjosi HMNH 001 (Galton 2007, p. 25) and CHE02.084 (Fig. 1b, d).

2. Prominent cingulum, very pronounced labially for maxillary teeth (Fig. 4b), stronger than in cf. S. armatus (e.g., Fig. 2c, e), more as in CHE02.084 (Fig. 1b).

3. Cingulum more inclined labiolingually (Fig. 3b) than in cf. S. armatus (Fig. 2d) and CHE02.084 (Fig. 1c, e), more as in the tooth of the holotype of $H$. mjosi HMNH 001 (Carpenter et al. 2001: fig. 3.5B).

4. The root is subcylindrical then strongly compressed mesiodistally (Fig. 3a) and curved labiolingually (Fig. 3b), contrary to cf. S. armatus (Fig. 2c-e) and CHE02.084 (Fig. 1b-e). 


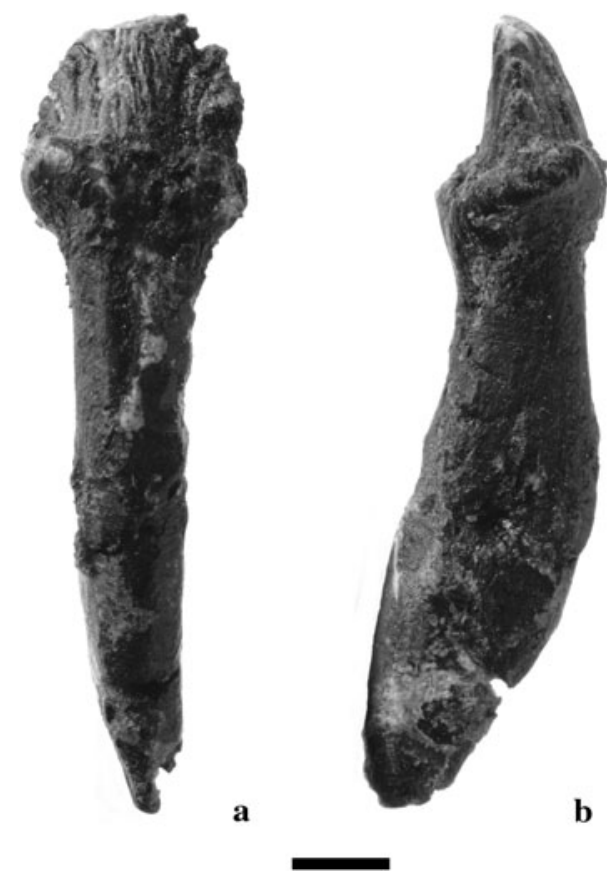

Fig. 3 Single isolated cheek tooth-with a poorly preserved crown but a well-preserved root—of Hesperosaurus mjosi (SMA 3074-FV01, specimen "Moritz"), from the Kimmeridgian-Tithonian (Late Jurassic) Morrison Formation of Howe-Scott Quarry, Howe Ranch, near Shell (Big Horn County, Wyoming, USA), in ?lingual (a) and mesial or distal (b) views. Scale bar $2 \mathrm{~mm}$

Based on these comparisons, the reported tooth shows both similarities and differences with those of cf. S. armatus and H. mjosi. Incidentally, Maidment et al. (2008) have considered-based on a postcranial comparison with S. armatus - that the type material of H. mjosi (Carpenter et al. 2001) is undiagnostic at the genus level and they proposed the new combination Stegosaurus mjosi. However, Carpenter (2010) considers that there are too many differences between the species armatus and mjosi for them to be referred to the same genus so he continues to recognize Hesperosaurus as a valid genus. Even though this debate is beyond the scope of this paper, it is noteworthy that the above observations indicate some dental differences between the two genera Stegosaurus and Hesperosaurus or species $S$. armatus and S. mjosi.

CHE02.084 is only ca. 5\% smaller than the teeth of SMA 3074-FV01 ("Moritz", Fig. 3) and SMA 0092 ("Lilly", Fig. 4), whose skeletons indicate total body lengths of 4.5 and $4.8 \mathrm{~m}$, respectively, whereas CHE02.084 is ca. 10-20\% smaller than the teeth-of various sizes-of SMA 0173DS-RCR2003-02 ("Sarah", Fig. 2), whose skeleton indicates a total body length of $5.6 \mathrm{~m}$ (the three skeletons have a similar total body height of $2.9 \mathrm{~m}$; Siber and Möckli 2009). This comparison indicates that CHE02.084 belongs to a medium-sized stegosaur, as these dinosaurs can reach up to approximately $9 \mathrm{~m}$ in length (Galton 1997).
Among the few remains of stegosaurs reported from the Middle-Late Jurassic of France, there are two genera: Lexovisaurus from the Callovian of Calvados-considered as a nomen dubium by Maidment et al. (2008) who proposed the new genus Loricatosaurus-and Dacentrurus from the Kimmeridgian of Seine-Maritime (Galton and Upchurch 2004; Maidment et al. 2008), that are known by skeletons (that of Dacentrurus was destroyed in World War II) lacking skulls. The other material of French stegosaurs consists of a vertebra from the Callovian of Sarthe (Buffetaut and Morel 2009) and a femur from the Kimmeridgian of Seine-Maritime (Galton and Boiné 1980). Consequently, no French dental remains are available for comparison. In the Early Cretaceous, no stegosaur remains have been previously reported from France. At the European scale, the Middle-Late Jurassic stegosaur osteological record also includes Lexovisaurus (Callovian of England) and Dacentrurus (Kimmeridgian-Tithonian of England, Portugal, Spain) material without skull or isolated teeth (Galton and Upchurch 2004). In addition, two other genera were reported from the Kimmeridgian-Tithonian Lourinhã Group of Portugal: Miragaia (Mateus et al. 2009) with cranial remains but without teeth, and Stegosaurus (Escaso et al. 2007) represented by a partial skeleton with the only known tooth from any European Jurassic stegosaur. This isolated and very small tooth $(\operatorname{LHNB}(\mathrm{CN})-1-01$; Escaso et al. 2007: Fig. 2o-p) displays:

1. A large "lingual" wear facet.

2. Numerous secondary ridges as in Stegosaurus but contrary to CHE02.084.

3. A prominent primary ridge on the "labial" face, merging with the cingulum, more for example as in Paranthodon (Late Jurassic-Early Valanginian, South Africa; Galton and Coombs 1981: fig. 1K-O; Galton and Upchurch 2004: fig. 16.5G-I) than in Stegosaurus (Gilmore 1914: fig. 11; Barrett 2001; Galton and Upchurch 2004: fig. 16.5A-D; pers. obs. at the Sauriermuseum Aathal, see above) and CHE02.084.

4. A cingulum upwardly arched on the "labial" face contrary to CHE02.084 (downwardly arched on the ?lingual face; Fig. 1d).

5. The complete root is straight, subcylindrical and slightly curved mesiodistally at the end as in cf. Stegosaurus (Fig. 2f).

Based on the primary ridge and the upwardly arched cingulum on the "labial" face, $\operatorname{LHNB}(\mathrm{CN})-1-01$ is different from CHE02.084; it is noteworthy that such a primary ridge was not reported in Stegosaurus. Escaso et al. (2007) referred the postcranial skeleton associated with LHNB(CN)-1-01 to $S$. cf. ungulatus whereas Maidment et al. (2008) considered it as S. armatus. Beyond this debate at the specific level, the presence of such a primary 

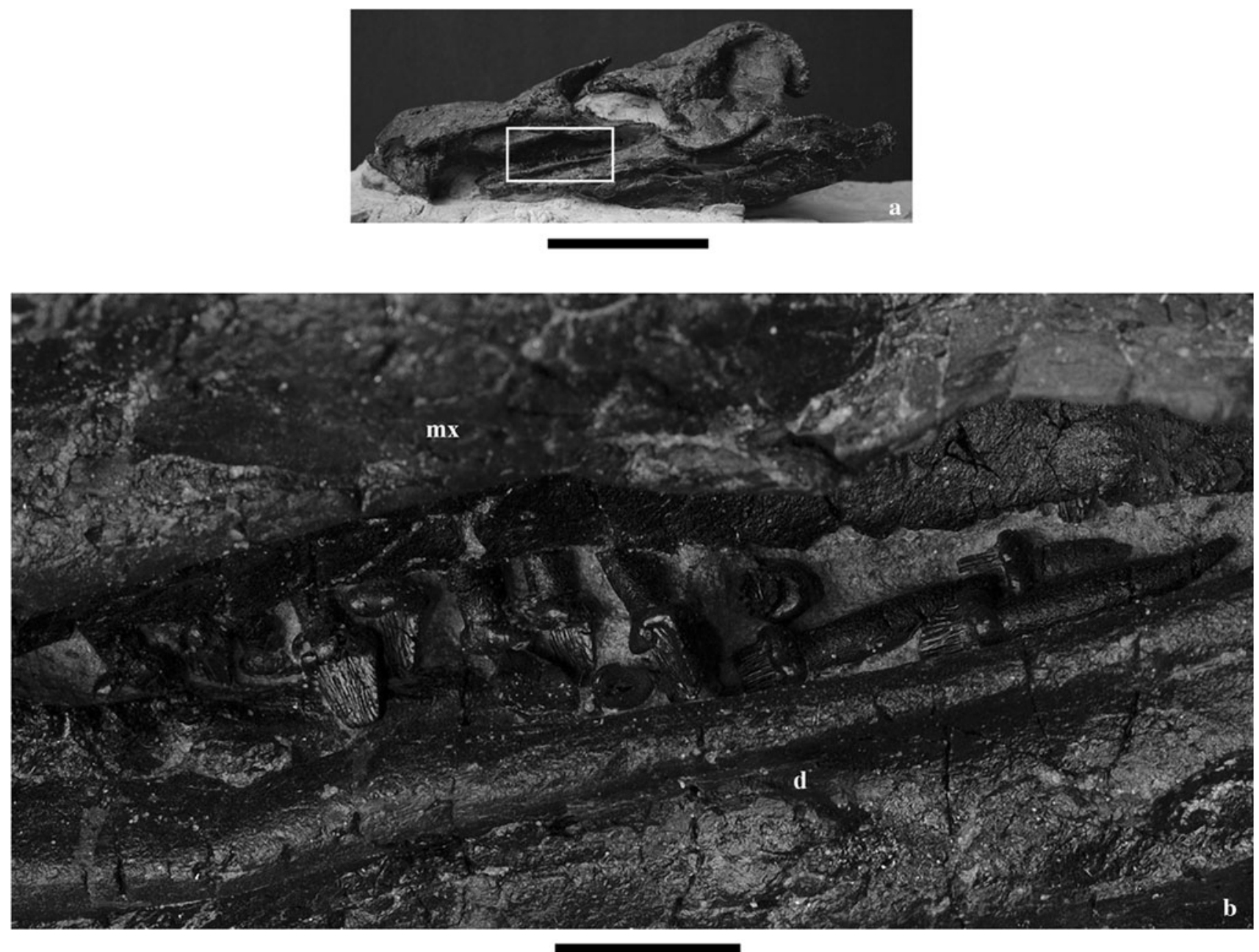

Fig. 4 Skull and tooth jaw of Hesperosaurus mjosi (SMA 0092, specimen "Lilly"), from the Kimmeridgian-Tithonian (Late Jurassic) Morrison Formation of Howe-Scott Quarry, Howe Ranch, near Shell (Big Horn County, Wyoming, USA). a Skull in left lateral view.

ridge could be linked to the tooth variability among the genus Stegosaurus. No other European dental material is available for comparison.

In the Early Cretaceous, European stegosaurs are represented by two English genera considered as nomina dubia (Galton and Upchurch 2004; Maidment et al. 2008): Craterosaurus from the Early Cretaceous (Potton Sands, reworked), based on an incomplete dorsal vertebra (Galton 1981; Galton and Upchurch 2004), and Regnosaurus from the Valanginian (Wealden Formation), defined on a partial mandible with some broken roots-subcircular in crosssection-in the alveoli but no tooth crowns (Barrett and Upchurch 1995) for comparison. Maidment et al. (2008) regarded Regnosaurus, which previously represented the only Early Cretaceous stegosaurian cranial material from Europe, as an indeterminate thyreophoran, but the dorsal vertebra remains a record of a Cretaceous stegosaur. Finally, no comparison is possible with the other few and b Magnified lateral view of the left jaw, with very well-preserved teeth, including several maxillary teeth still in original position, and possibly some displaced dentary teeth in the posterior part. $d$ dentary, $m x$ maxilla. Scale bars $1 \mathrm{~cm}(\mathbf{b}), 10 \mathrm{~cm}(\mathbf{a})$

fragmentary postcranial specimens previously described as stegosaurian from England and Spain (e.g., dermal spines from the Hauterivian-Barremian of El Castellar and Camarillas Formations, Galve, Teruel; Pereda Suberbiola et al. 2005), and now considered as indeterminate thyreophorans or other dinosaurs by Maidment et al. (2008).

The reported tooth shows the best similarities with Stegosaurus and Hesperosaurus, but it cannot be assigned to these Late Jurassic genera. The shape of the ?lingual cingulum (maxillary tooth hypothesis) is different, strongly arched downwards (V-shaped) rather than upwards (e.g., Galton 2007: fig. 2.6B, maxillary tooth 20). The shape of the cingulum is, however, a quite variable character in stegosaurs (Galton and Upchuruch 2004: fig. 16.5; pers. obs. between cf. Stegosaurus and Hesperosaurus; difference between LHNB(CN)-1-01 and other known Stegosaurus). In the same way, Coombs (1990) has observed a high variability of this character in ankylosaurs, even in a single individual. Thus 
CHE02.084 is insufficient for a precise identification at the generic level; according to the combination of the above features it is not characteristic for any other known stegosaur. At the family level, CHE02.084 being different from cheek teeth of Huayangosaurus from the Middle Jurassic of China (Galton and Upchurch 2004: fig. 16.5.J)—-the single genus of the primitive family Huayangosauridae-it could be referred by default to the other stegosaur family, the Stegosauridae. However, here the tooth from Cherves-de-Cognac is referred to as Stegosauria indet.

\section{Discussion and conclusions}

\section{Fossil record}

The discovery of a stegosaur tooth in the Berriasian of Cherves-de-Cognac is the first record of this dinosaur group in the Early Cretaceous of France. Even though the reported tooth cannot be assigned to the known French Middle-Late Jurassic genera Lexovisaurus (or Loricatosaurus) and Dacentrurus (Galton and Upchurch 2004; Maidment et al. 2008), it indicates that stegosaurs were present in France throughout the Jurassic-Cretaceous transition. On the European scale, it adds a key element to the very impoverished fossil record of stegosaurs during the Early Cretaceous. According to the recent review by Maidment et al. (2008) of the few and fragmentary remains of stegosaurs from the Early Cretaceous of Europe (England and Spain), only the partial vertebra of the nomen dubium Craterosaurus, poorly dated to the Aptian (reworked from the ?Valanginian or Barremian) of England (Galton 1981; Galton and Upchurch 2004), would belong to a stegosaur. If we follow this review, the tooth from the Berriasian of Cherves-de-Cognac would appear as the second and oldest known representative of a stegosaur in the Early Cretaceous of Europe. Elsewhere, it is the second stegosaurian tooth crown reported from this continent, along with that of a Stegosaurus from the Late Jurassic of Portugal (Escaso et al. 2007). Except for these teeth, cranial remains of stegosaurs are very rare in Europe, including only the partial skull (lacking teeth) of Miragaia from the Late Jurassic of Portugal (Mateus et al. 2009) and the mandibule (with some broken roots but no tooth crowns) of Regnosaurus from the Valangianian of England (Barrett and Upchurch 1995), that has been interpreted as an indeterminate thyreophoran (Maidment et al. 2008).

Palaeobiology and palaeoecology

The reported stegosaur tooth testifies the presence of a medium-sized individual (ca. $4.5 \mathrm{~m}$ in total body length) of a heavily built quadrupedal herbivore and low-level browser stegosaur likely foraging within a meter from the ground (Galton 1997). The occasional presence of small, low-angled planar wear facets at the apical tip of the tooth crowns in Stegosaurus (e.g., in the maxillary tooth row of USNM 4934, Gilmore 1914: fig. 12, Galton 2007: figs. 2.5D, F, 2.6B, D; in isolated cheek teeth, Galton and Upchurch 2004: fig. 16.5C; pers. obs. in isolated cheek teeth of SMA 0173-DS-RCR2003-02: Fig. 2b, c, f), and more generally in stegosaurs, have been interpreted by Barrett (2001) as the result of tooth-food rather than toothtooth (occlusion) wears (see also Galton 2007, p. 25). The presence of such a wear facet in CHE02.084 then suggests a tooth-vegetation contact; the only remains of vegetation reported from Cherves-de-Cognac are woods of Agathoxylon (Philippe in El Albani et al. 2004) but no direct diet relationship can be established. Elsewhere, the prominent cingulum in CHE02.084, also known in other stegosaurs (Galton and Upchurch 2004) and here observed in cf. Stegosaurus armatus (Fig. 2) and Hesperosaurus mjosi (Figs. 3, 4), most likely acted as a protective structure to reduce pressure forces caused by soft food, as shown by Anderson et al. (2009) with Finite Element models in basal mammal teeth.

The described stegosaur tooth was found in the same bed as two other ornithischian dinosaurs also represented by single isolated teeth. These are two ornithopods including an indeterminate iguanodontian (Billon-Bruyat 2003: fig. 35D; Pouech et al. 2006: fig. 1Q) found in close proximity (ca. $1 \mathrm{~m}$ ) of CHE02.084 and a heterodontosaurid (Pouech et al. 2006: fig. 1R). In addition, the Cherves-deCognac locality has yielded remains of saurischian dinosaurs, including several teeth and a few bones of small and large theropods (a dromaeosaurid and a Theropoda indet.), two isolated teeth, an isolated caudal vertebra and a partial disarticulated skeleton of a camarasaurid (Le Loeuff et al. 1996; Billon-Bruyat 2003; Mazin et al. 2006; Pouech et al. 2006; Pouech 2008). On the whole, this Berriasian terrestrial faunal assemblage of southwestern France therefore includes a diverse fauna of dinosaurs, with theropods, sauropods, stegosaurs and ornithopods.

The assemblage of ornithischians from Cherves-deCognac shares some similarities with that from the Early Cretaceous (Berriasian) of the Purbeck Limestone Group of southern England, reviewed by Norman and Barrett (2002). This latter includes two similar medium and small-sized ornithopods, the iguanodontian Camptosaurus-recently challenged by Galton (2009) who proposed the new noncamptosaurid genus Owenodon-and the heterodontosaurid Echinodon, respectively. In addition, it includes a nodosaurid ankylosaur represented by a single isolated tooth, initially ascribed to a stegosaur (for a description and historical background see Galton 1983). Thus thyreophoran dinosaurs are represented in both assemblages but with two 
different major groups hitherto, the stegosaurs in Chervesde-Cognac and the ankylosaurs in the British Purbeck. The rarity of stegosaur and ornithopod teeth-among the thousands of vertebrate micro-remains-in Cherves-deCognac suggests that these herbivores were mainly inhabitants of a distal or inland terrestrial (away from channels) palaeoenvironment (allochthones), or occasional residents (parautochthones) rather than minor elements (autochthones) of a coastal fauna. It supports the assumption that the rarity of osteological remains of ornithischians in the British Purbeck environment is linked just to "passers by" dinosaurs (Norman and Barrett 2002).

Acknowledgments JPBB is particularly grateful to H.J. "Kirby" Siber and his team for the kind invitation to the Symposium on Stegosauria (June 2009) and access to the stegosaur material in the Sauriermuseum Aathal. We are indebted to our excavation team, especially S. Blineau who discovered the specimen. We thank P. Tafforeau and the ID 19 beamline staff of the European Synchrotron Radiation Facility (Grenoble, France) for their help in obtaining microtomographic images, and B. Migy (SAP, Porrentruy; Figs. 1a; 2a-g; 3a, b) and U. Möckli (Sauriermuseum Aathal; Fig. 4b) for photographs. We thank Nicolai A. Christiansen (Museu da Lourinhã), D. Becker and L. Bocat (SAP, Porrentruy) for fruitful discussions about this tooth and/or the first version of this manuscript. The manuscript benefited greatly from the comments of the two referees P.M. Galton (University of Bridgeport and Peabody Museum of Natural History, Yale University, USA) notably concerning the identification and comparisons with USNM 4934 and the literature, and P. Barrett (The Natural History Museum, London, UK), the latter who prefers to regard CHE02.084 as a thyreophoran or possibly an ankylosaur tooth. We also thank D. Marty (SAP, Porrentruy) for editorial work. Fieldwork was supported by the Champlanc Quarry owner (Groupe Garandeau), several local Public Councils (Ville de Cherves-deCognac, Communauté de Communes de Cognac, Département de la Charente) and societies (GERMA, PaleoAquitania).

\section{References}

Allain, R., \& Pereda Suberbiola, X. (2003). Dinosaurs of France. Comptes Rendus Palevol, 2, 27-44.

Anderson, P., Gill, P., \& Rayfield, E. (2009). How the cingula of basal mammal teeth may alleviate strain in the enamel caused by a soft food diet. Journal of Vertebrate Paleontology, 29(suppl. 3), 54A.

Barrett, P. M. (2001). Tooth wear and possible jaw action of Scelidosaurus harrisonii Owen and a review of feeding mechanisms in other thyreophoran dinosaurs. In K. Carpenter (Ed.), The Armored Dinosaurs (pp. 25-52). Bloomington: Indiana University Press.

Barrett, P. M., \& Upchurch, P. (1995). Regnosaurus northamptoni, a stegosaurian dinosaur from the lower Cretaceous of southern England. Geological Magazine, 132, 213-222.

Benton, M. J. (1995). Diversification and extinction in the history of life. Science, 268, 52-58.

Billon-Bruyat, J.-P. (2003). Les écosystèmes margino-littoraux du Jurassique terminal et du Crétacé basal d'Europe occidentale: biodiversité, biogéochimie et l'événement biotique Jurassique/ Crétacé. Unpublished PhD Thesis, University of Poitiers, 254 pp.

Bourgeuil, B., Hantzpergue, P. \& Moreau, P. (1986). Notice explicative de la feuille Matha (684) à 1/50 000. BRGM, Orléans, $25 \mathrm{pp}$.
Buffetaut, E., Cuny, G., \& Le Loeuff, J. (1991). French dinosaurs: The best record in Europe? Modern Geology, 16, 17-42.

Buffetaut, E., \& Morel, N. (2009). A stegosaur vertebra (Dinosauria: Ornithischia) from the Callovian (Middle Jurassic) of Sarthe, western France. Comptes Rendus Palevol, 8, 545-549.

Buffetaut, E., Pouit, D., Rigollet, L., \& Archambeau, J.-P. (1989). Poissons et reptiles continentaux du Purbeckien de la région de Cognac (Charente). Bulletin de la Société Géologique de France, $5,1065-1069$.

Carpenter, K. (2010). Species concept in North American stegosaurs. Swiss Journal of Geosciences, 103. doi: 10.1007/s00015-0100020-6

Carpenter, K., Miles, C. A., \& Cloward, K. (2001). New primitive stegosaur from the Morrison formation, Wyoming. In K. Carpenter (Ed.), The armored dinosaurs (pp. 55-75). Bloomington: Indiana University Press.

Colin, J.-P., El Albani, A., Fursich, F. T., Martin-Closas, C., Mazin, J.M., \& Billon-Bruyat, J.-P. (2004). Le gisement « Purbeckien » de vertébrés de Cherves-de-Cognac, Charente (SW France): nouvelles données biostratigraphiques. Comptes Rendus Palevol, 3, 9-16.

Coombs, W. P. Jr. (1990). Teeth and taxonomy in ankylosaurus. In K. Carpenter \& P. J. Currie (Eds.), Dinosaur systematics. Approaches and perspectives (pp. 269-279). Cambridge: Cambridge University Press.

Coombs, W. P., Jr., \& Maryańska, T. (1990). Ankylosauria. In D. B. Weishampel, et al. (Eds.), The Dinosauria (pp. 456-483). Berkeley: University of California Press.

Coquand, H. (1860). Description physique, géologique, paléontologique et minéralogique du département de la Charente, Tome deuxième. Barlatier-Feissat et Demonchy, Marseille, 420 pp.

Delfaud, J., \& Gottis, M. (1966). Sur quelques figures de sédimentation dans le Portlandien du Lot et sur leur cadre paléogéographique en Aquitaine septentrionale. Actes de la Société Linnéenne de Bordeaux B7, 103, 3-9.

El Albani, A., Fürsich, F. T., Colin, J.-P., Meunier, A., Hochuli, P., Martín-Closas, C., et al. (2004). Palaeoenvironmental reconstruction of the basal Cretaceous vertebrate bearing beds in the Northern part of the Aquitaine Basin (SW France): Sedimentological and geochemical evidence. Facies, 50, 195-215.

El Albani, A., Meunier, A., \& Fürsich, F. T. (2005). Unusual occurrence of glauconite in a shallow lagoonal environment (Lower Cretaceous, northern Aquitaine basin, SW France). Terra Nova, 17, 537-544.

Escaso, F., Ortega, F., Dantas, P., Malafaia, E., Pimentel, N. L., Pereda-Suberbiola, X., et al. (2007). New evidence of shared dinosaur across Upper Jurassic Proto-North Atlantic: Stegosaurus from Portugal. Naturwissenschaften, 94, 367-374.

Fara, E., \& Benton, M. J. (2000). The fossil record of Cretaceous tetrapods. Palaios, 15, 161-165.

Galton, P. M. (1981). Craterosaurus pottonensis Seeley, a stegosaurian dinosaur from the lower Cretaceous of England, and a review of Cretaceous stegosaurs. Neues Jahrbuch für Geologie und Paläontologie Abhandlungen, 161, 28-46.

Galton, P. M. (1983). Armored dinosaurs (Ornithischia: Ankylosauria) form the middle and upper Jurassic of Europe. Palaeontographica Abt. A, 182, 1-25.

Galton, P. M. (1990). Stegosauria. In D. B. Weishampel, et al. (Eds.), The Dinosauria (pp. 435-455). Berkeley: University of California Press.

Galton, P. M. (1997). Stegosauria. In P. J. Currie \& K. Padian (Eds.), Encyclopedia of Dinosaurs (pp. 701-703). San Diego: Academic Press.

Galton, P. M. (2007). Teeth of ornithischian dinosaurs (mostly Ornithopoda) from the Morrison Formation (Upper Jurassic) of the Western United States. In K. Carpenter (Ed.), Horns and Beaks (pp. 17-47). Bloomington: Indiana University Press. 
Galton, P. M. (2009). Notes on Neocomian (Lower Cretaceous) ornithopod dinosaurs from England-Hypsilophodon, Valdosaurus, "Camptosaurus", "Iguanodon"—and referred specimens from Romania and elsewhere. Revue de Paléobiologie, 28, 211-273.

Galton, P. M., \& Boiné, G. (1980). A stegosaurian dinosaur femur from the Kimmeridgian beds (upper Jurassic) of the Cap de la Hève, Normandy. Bulletin Trimestriel de la Société Géologique de Normandie et des Amis du Muséum du Havre, 67, 31-38.

Galton, P. M., \& Coombs, W. P. Jr. (1981). Paranthodon africanus (Broom), a stegosaurian dinosaur from the lower Cretaceous of South Africa. Geobios, 14, 299-309.

Galton, P. M., \& Upchurch, P. (2004). Stegosauria. In D. B. Weishampel, et al. (Eds.), The Dinosauria (2nd ed., pp. 343-362). Berkeley: University of California Press.

Gilmore, C. W. (1914). Osteology of the armored Dinosauria in the United States National Museum, with special reference to the genus Stegosaurus. United States National Museum, Bulletin, 89, $1-143$.

Hallam, A. (2001). A review of the broad pattern of Jurassic sea-level changes and their possible causes in the light of current knowledge. Palaeogeography, Palaeoclimatology, Palaeoecology, 167, 23-37.

Hantzpergue, P., \& Lafaurie, G. (1994). Les calcaires lithographiques du Tithonien quercynois: stratigraphie, paléogéographie et contexte biosédimentaire. Geobios MS, 16, 237-243.

Haubold, H. (1990). Dinosaurs and fluctuating sea levels during the Mesozoic. Historical Biology, 4, 75-106.

Hervat, P., \& Hervat, M. (1993). Découverte de Polyacrodus parvidens (Woodward, 1916) (Elasmobranchii, Hybodontoidea) dans un faciès purbeckien (Tithonien supérieur) du Charentais (France). Cossmanniana H.S., 2, 43-48.

Le Loeuff, J., Buffetaut, E., \& Merser, C. (1996). Découverte d'un dinosaure sauropode tithonien dans la région de Cognac (Charente). Géologie de la France, 2, 79-81.

Maidment, S. C. R., Norman, D. B., Barrett, P. M., \& Upchurch, P. (2008). Systematics and phylogeny of Stegosauria (Dinosauria: Ornithischia). Journal of Systematic Palaeontology, 6, 367-407.

Marsh, O. C. (1896). The dinosaurs of North America. In: United States Geological Survey, 16th Annual Report 1894-1895, pp 133-244.

Mateus, O., Maidment, S. C. R., \& Christiansen, N. (2009). A new long-necked 'sauropod mimic' stegosaur and the evolution of the plated dinosaurs. Proceedings of the Royal Society B, 276, $1815-1821$.

Mazin, J.-M., Billon-Bruyat, J.-P., Pouech, J. \& Hantzpergue, P. (2006). The Purbeckian site of Cherves-de-Cognac (Berriasian, Early Cretaceous, southwestern France): A continental ecosystem accumulated in an evaporitic littoral depositional environment. In: P. M. Barrett \& S. Evans (Eds.) Ninth International Symposium on Mesozoic Terrestrial Ecosystems and Biota, Abstracts and Proceedings, pp. 84-88.

Norman, D. B. (1984). A systematic reappraisal of the reptile order Ornithischia. In W.-E. Rief \& F. Westphal (Eds.), Third symposium on Mesozoic Terrestrial Ecosystems, Short Papers (pp. 157-162). Tübingen: Attempto Verlag.

Norman, D. B., \& Barrett, P. M. (2002). Ornithischian dinosaurs from the lower Cretaceous (Berriasian) of England. Special Papers in Palaeontology, 68, 161-189.

Pereda Suberbiola, X., Galton, P. M., Ruiz-Omeñaca, J. I., \& Canudo, J. I. (2005). Dermal spines of stegosaurian dinosaurs from the lower Cretaceous (Hauterivian-Barremian) of Galve (Teruel, Aragon, Spain). Geogaceta, 38, 35-38.

Pouech, J. (2008). Position des Mammifères dans les écosystèmes mésozoïques d'Europe Occidentale. Le site de Cherves-deCognac (Berriasien, Charente, France). Unpublished PhD Thesis, University of Lyon 1, 274 pp., 89 plates.

Pouech, J., Mazin, J.-M. \& Billon-Bruyat, J.-P. (2006). Microvertebrate biodiversity from Cherves-de-Cognac (Lower Cretaceous, Berriasian: Charente, France). In: P. M. Barrett \& S. Evans (Eds.) Ninth International Symposium on Mesozoic Terrestrial Ecosystems and Biota, Abstracts and Proceedings, pp 96-100.

Sander, P. M. (1997). Teeth and jaws. In P. J. Currie \& K. Padian (Eds.), Encyclopedia of Dinosaurs (pp. 717-725). San Diego: Academic Press.

Sereno, P. C. (1998). A rationale for phylogenetic definitions, with application to the higher-level taxonomy of Dinosauria, Neues Jahrbuch für Geologie und Paläontologie. Abhandlungen, 210, 41-83.

Siber, H. J. \& Möckli, U. (2009). The Stegosaurs of the Sauriermuseum Aathal. Sauriermuseum Aathal, Aathal, $56 \mathrm{pp}$.

Thierry, J. \& Barrier, E., et al. (41 co-authors) (2000). Early Tithonian (141-139 Ma), Map 11. In: J. Dercourt et al. (Eds.) Atlas PériTéthys, palaeogeographical maps. CCGM/CGMW, Paris.

Vickaryous, M. K., Maryańska, T., \& Weishampel, D. B. (2004). Ankylosauria. In D. B. Weishampel, et al. (Eds.), The Dinosauria (2nd ed., pp. 363-392). Berkeley: University of California Press.

Vignaud, P., de Broin, F., Brunet, M., Cariou, E., Hantzpergue, P. \& Lange-Badré, B. (1994). Les faunes de vertébrés jurassiques de la bordure Nord-Orientale du Bassin d'Aquitaine (France): Biochronologie et environnements. Geobios MS, 17, 493-503.

Ziegler, P. A. (1988). Evolution of the Artic-North Atlantic and the Western Tethys. AAPG Mem 43, pp. 1-198, plate 14 (Early Cretaceous, Berriasian-Barremian). 